[Bull. Agr. Chern. Soc. Japan, Vol. 23, No. 3, p. 145 149, 1959]

\title{
Action of Lysozyme and Some Microbial Enzymes on Acid-Resistant Organisms
}

\author{
(Studies on Bacteriolytic Substances produced by Microorganisms, Part 5) \\ By Yukio Satomura, Shigetaka Okada and Juichiro Fukumoto \\ Institute of Polytechnics, Osaka City University
}

Received August 6, 1958

\begin{abstract}
Cells of an avian tubercle bacillus, when developed into weak acid-fastness were found to be easily susceptible to egg-white lysozyme but not sensitive to bacterial lysozyme. The cells of normal acid-fastness, on the contrary, were resistant to the egg-lysozyme and lysed only by successive application of egg-lysozyme and fungal enzymes. Heat treatment at about $60^{\circ}$ changed the acid-fast cells to cells quite sensitive to lysozyme.
\end{abstract}

\section{INTRODUCTION}

The action of lysozyme has long been employed as a useful means in cytochemical studies of many species of bacteria ${ }^{1,2}$, but so far few reports have been published on the study of tubercle bacilli and lysozyme ${ }^{33}$. Lysis of bacterial cell by lysozyme is attributed to the dissolution of a polysaccharide which plays a part in the maintenance of the cell-wall structure $^{4}$. Accordingly, it is doubtful whether complete lysis can be expected if this lysozyme sensitive polysaccharide in the cell wall were combined with other cell wall constituents into such a complex in which the susceptible polysaccharide could be protected from the direct attack of lysozyme. Concerning this, the effects of physical or chemical pretreatment of the cells and that of a combined-attack by lysozyme and other enzymes on the lysis were thought to be of special interest ${ }^{5,67,7)}$. Rencently, it has

1) K. Meyer, J. W. Palmer, R. Thompson and D. Khorazo, J. Biol. Chem., 113, 479 (1936).

2) M. R. J. Salton, Bacterial. Revs., 21, 82 (1957).

3) Q. N. Myrvik, R. S. Weiser and H. D. Agar, Am. Rev. Tuberc., 67,217 (1953).

4) M. R. J. Salton, 3 eme congres international de Biochimie, 27 (1955).

5) G. H. Warren, J. Geay and P. Bartell, J. Bacteriol., 70, 614 (1955).

6) M. E. Becker and S. E. Hartsell, Arch. Biochem. Biopbys." 53, 402 (1954), 55, 257 (1955).

7) R. Repaske, Biocbim. Biopbys. Acta, 22, 189 (1956). been observed that a lysozyme sensitive polysaccharide really exists in several species of lysozyme-resistant bacteria ${ }^{67,8)}$. Also, the application of enzymes other than lysozyme such as ribonuclease, lipase and phospholipase etc. has become available from studies concerning the composition of cell-wall ${ }^{9}$. In addition to the enzymatic action, the lysozyme has been known from its basicity to cause an osmotical change to bacterial cells by a certain basic antibacterial polypeptide such as tyrocidin ${ }^{10}$. Formerly, a killing action of lysozyme for tubercle bacilli had been proved ${ }^{3,11}$, but the existence of lysozyme-substrate polysaccharide has not yet been recognized hitherto. On the other hand, the physiological significance of fat and wax contained in acid-fast cells has attracted attention of some workers and, a lysis of the cells by lipolytic enzyme such as wax-decomposing enzyme "cerase" has been reported"

However, a further detailed investigation would be necessary for the structural features

8) R. G. Peterson and S. E. Hartsell, J. Inf. Diseases, 96, 75 (1955).

9) H. W. Dorglas and F. Parker, Biachem. J., 68, 94 (1958).

10) A. K. Raymond, M. J. Kingkade, S. K. Kern, and O. K. Behrens, J. Bascteriol., 61, 171 (1951).

11) Q.N. Myrvid, R.S. Weister and M. C. Kelly, Am. Rev. Tuberc, 68, 584 (1955).

12) M. K. Muftic, C. A., 46, 7167 (1952), Enzymologia, 17, 222 (1955) 
of carbohydrate components of the cell-wall of acid-fast bacilli similary as in the case of many other bacterial cells. In this paper, some aspects of the cell-wall structure of an avian tubercle bacillus are demonstrated, using lysozyme and some microbial enzymes as analytical tools.

\section{EXPERIMENTAL}

Methods and Materials.

Cultures and preparation of suspension of washed bacteria; Some relations of acid-fastness with cultural conditions in the same strain of an avian tubercle bacillus are presented in Table I. Bacterial cells of both the acid-fast type and non acid-fast type were employed in the following experiments. Cellswere harvested and resuspended in a phosphate buffer solution after washing and grinding three times with distilled water. The turbidity of the cell-suspension was adjusted to $10 \%$ transmission in measuring optical density at $600 \mathrm{~m} / \mu$ with an electric spectrophotometer.

TABle I. ACID-Fastness and Cultural CONDITIONS

\begin{tabular}{|c|c|c|c|}
\hline \multirow{2}{*}{ Medium } & Glucose $\quad 206$ & $\begin{array}{l}\text { Tween } 80 \\
\text { H Cl }\end{array}$ & $0.5 \rho$ \\
\hline & Polypepton $0.5 \%$ & Salts* & \\
\hline Temperature & $37^{\circ}$ & $37^{\circ}$ & \\
\hline Growth-Time & $12 \mathrm{hr}$ & $48 \mathrm{hr}$ & \\
\hline Shape & rod & spherical & \\
\hline Acid-fastness &,- \pm & + & \\
\hline
\end{tabular}

Salts*: $\mathrm{Na}_{2} \mathrm{HPO} 40.65, \mathrm{KH}_{2} \mathrm{PO}_{4} 0.1, \mathrm{MgSO}_{4} \cdot 7 \mathrm{H}_{2} \mathrm{O} 0.02 \%(\mathrm{pH} 7.0)$

Enzyme preparations: Egg-white lysozyme was crystallized by the method of Alderton ${ }^{13}$. Bacterial lysozyme was obtained from the culture of Bacillus subtilis and purified by the method using ion-exchange resin, previously reported ${ }^{14}$ ). Enzymes of Sclerotinia fungus were extracted from the bran culture with a ten-fold volume of water and the extract was concentrated five times its volume and dialysed. Although the bran culture of Sclerotinia fungus possessed a lipase the aqueous extract had no lipase activity ${ }^{15)}$. The crystalline trypsin used here, was of an Armers product and commercial pancreatin was used as the extract with water.

13) G. Alderton and H. L. Fevold, J. Biol. Chem., 164, I (1946).

14) Y. Satomura, S. Okada and J. Fukumoto, J. Agr. Chem. Soc. Japan., 31, 801 (1957).

15) Y. Satomura and S. Oi, J. Agr. Chem. Sor. Japan., 31, 202 (1957).
Measurement of lysis: A suspension of washed bacterial substrate was mixed with the various enzyme solutions and, after adjusting the $\mathrm{pH}$ with $\mathrm{M} / 10$ phosphate buffer, incubated at $37^{\circ}$. Lysis was followed by the turbidimetric method with the use of a spectrophotometer, or by weighing the dry weight of cells remaining after centrifuging.

Analytical methds: The increase in viscosity was measured by Ostwald's viscosimeter and the degree of liberation of nucleic acid (PNA) was determined by the 'Orcin-HCI' reaction. The release and dissolution of cell-wall mucopolysaccharide was estimated by measuring the turbidity which appeared by the addition of acidified horse serum ${ }^{16)}$.

\section{Action of Lysozyme}

From the experiments shown in Fig. 1. it is distinct that the non acid-fast cells are easily lysed by the action of lysozyme alone whereas, the acid-fast cells are not lysed even by the combined action of trypsin and
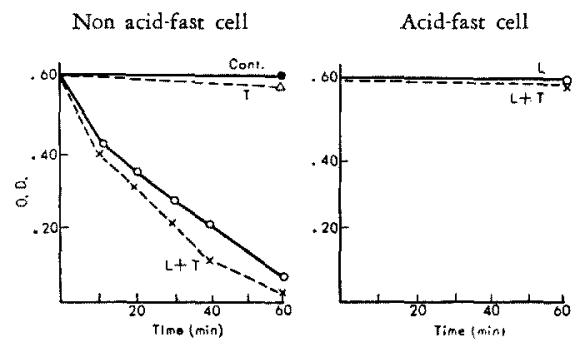

FIG. 1. Susceptibility of Acid-Fast and Non Acid-Fast Cells to Lysozyme (Incubation at $37^{\circ}$ )

$-\mathrm{O}-\mathrm{L}, \quad$ Lysozyme $25 \mu \mathrm{g} / \mathrm{ml}$

$--x--\mathrm{L}+\mathrm{T}$, Lysozyme $25 \mu \mathrm{g} / \mathrm{ml}$ Trypsin $250 \mu \mathrm{g} / \mathrm{ml}$

$--\Delta--\quad T, \quad$ Trypsin $250 \mu \mathrm{g} / \mathrm{ml}$

- Cont. No addition

TABLE II. ADSORPTION OF LXSOZYME TO CELLS Lysozyme Activity

Initial Remaining Rate of

Cell Types no addition after addition Adsorption

of cells of cells $\%$

Non Acid-Fast $\quad 400 \quad 4 \quad 99$

$\begin{array}{llll}\text { Acid-Fast } & 400 & 300 & 25\end{array}$

$\left(\begin{array}{l}\text { Lysozyme } \\ \text { Non-Sensitive } \\ \text { Bacteria }\end{array}\right) \quad$ (400)

E. coli

Treatment

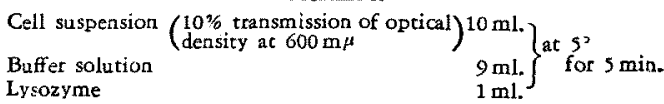

16) K. Meyer, Physiol. Revs., 27, 335 (1947). 
lysozyme. In Table II, the difference in the degree of lysozyme adsorption of both types of cells is given. Thus, it can be supposed that the polysaccharidesubstrate of lysozyme surely exists in cells of the non acid-fast type, as observed in the other lysozymesensitive bacterial cells which readily adsorb lysozyme.

Joint Action of Lysozyme with other Enzymes

As seen in Table III, egg-white lysozyme dissolves only $22 \sim 23 \%$ of the weight of the acid-fast cells even in a prolonged period of $18 \sim 20 \mathrm{hr}$. at $\mathrm{pH} 6.0$, while the enzyme solution of Sclerotinia digests cells up to about 50\% in the same conditions. Bacterial lysozyme possesses only scanty activity. However, a certain combined-use of these agents gave a particulary accelerated lysis action. When the Sclerotinia extract was combined with egg-white lysozyme in the above condition, it digested the cells up to ca. $70 \%$, which is equal to the sum of lysis power of both agents. When however, the cells were pretreated with lysozyme for about $2 \mathrm{hrs}$. at pH 6.0 and centrifuged, resuspended in a buffer of $\mathrm{pH} 4.0$ and then successively treated with Sclerotinia extract, lysis extended up to more than $80 \%$ within a period of 4 hours. From the results obtained, it was supposed that an inbibitory effect on the action of lysozyme had been caused by an acidic substance contained in the fungus extract, which can combine

TABLE III. SINGLE OR JOINT ACTION OF LYSOZYME AND OTHER ENZYMES ON THE CELLS OF ACID-FAST TYPE

$$
\begin{aligned}
& \begin{array}{lc}
\text { Cell } & \begin{array}{c}
\text { Rate of } \\
\text { Lysis }
\end{array} \\
\text { Suspension + S } 18 \sim 20 \mathrm{hr}\left(\mathrm{pH} \mathrm{6.0)} 37^{\circ}\right. & \rightarrow \begin{array}{l}
46.0 \% \% \\
\text { (pH 4.0) }
\end{array}
\end{array} \\
& +\mathrm{L}^{18 \sim 20 \mathrm{hr}(\mathrm{pH} 6.0) 37^{\circ}} \rightarrow 22.5 \\
& + \text { Panc. ........" } \rightarrow 19.5 \\
& + \text { Try. } \longrightarrow 2.0 \\
& + \text { Bact. L } \quad \longrightarrow \quad \longrightarrow 9.5 \\
& +(\mathrm{S}+\mathrm{L}) \quad-\quad \prime \quad \ldots 70.6 \\
& +\mathrm{L}^{2 \mathrm{hr}(\mathrm{pH} 6.0)} \mathrm{s}^{4 \mathrm{hr}(\mathrm{pH} \mathrm{4.0)}} \rightarrow 83.2 \\
& \text { + Panc. " ". S S II } \rightarrow 59.7 \\
& \text { + Bact. L } \quad \text { L } \quad \mathrm{S} \quad \text { " } \rightarrow 54.8 \\
& \text { (in Final concentration) } \\
& \text { Sclerorinia fungus-enzyme. } 10 \text { times water extracts of hran } \\
& \text { culture } \\
& \text { L: Egg-white lysozyme, } \quad 30 \mu \mathrm{g} / \mathrm{ml} \\
& \text { Panc.: Pancreatin, } 1 \% \text { aqueous extrucr } \\
& \text { Try: Trypsin. } \\
& \text { Bact. L: Bacterial lysozyme } \\
& 100 \mu \mathrm{g} / \mathrm{ml} \\
& \text { ca. } 50 \mu \mathrm{g} / \mathrm{mL} \\
& \text { Rate of Lysis }=\text { Cell-temains }\left(\frac{\text { Control }- \text { Test }}{\text { control }}\right) \times 100
\end{aligned}
$$

with lysozyme. In the same procedure, pancreatin pretreatment plus Sclerotinia extract attained a ca. $60 \%$ lysis, and bacterial lysozyme plus Sclerotinia extract ca. $55 \%$ lysis. In these experiments Sclerotinia extract lost its activity upon heating at $100^{\circ}$ for 10 minutes.

It was also demonstrated that the Sclerotinia enzyme extract attacked the polysaccharide fraction of the acidfast cells to produce a small quantity of reducing sugar, decreasing the viscosity of the solution. As main sugars of the polysaccharide constitutents glucosamine, glucose, mannose and rhamnose were detected by a paperchromatographic test after acid hydrolysis.

\section{Susceptibility of Heated Cells to Lysozyme}

As described above, the sensitivity of acid-fast cells to lysozyme was very weak in an intact state, but sensitivity was found to be increased by heating the cells at about $60^{\circ}$ for $10 \mathrm{~min}$. in distilled water, thus bringing about the Nakamura effect ${ }^{(7)}$. As shown in Fig. 2, the heated cell-suspension rather increases its turbidity in the earlier stage of incubation with lysozyme, as in the case with heat-killed cells of other lysozyme sensitive or non sensitive bacteria ${ }^{2)}$, but prompt lysis occurs upon the addition of $\mathrm{NaOH}$ changing the $\mathrm{pH}$ from 6 to 12 , concurrently increasing viscosity. However, the Nakamura effect did not appear with the cells heated at temperatures lower than $50^{\circ}$ or higher than $70^{\circ}$. Also, the effect was not observed with the cells previously treated with a dilute $\mathrm{HCl}$ or $\mathrm{NaOH}$ solution. The degree of clearing, viscosity and the amount of nucleic acid released from the cells, increased in parallel

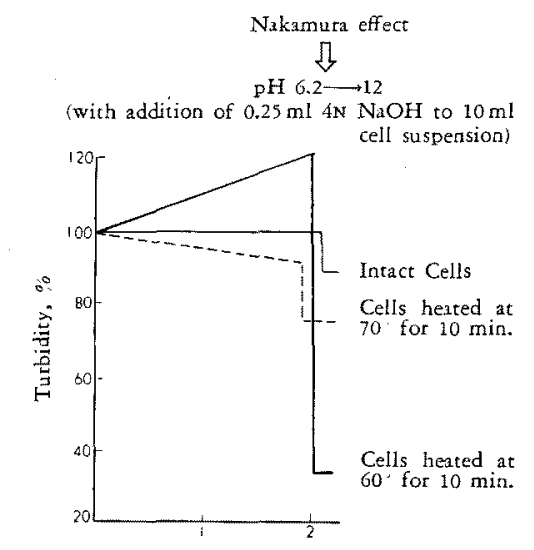

Hours incubating wich Lysozyme $(125 \mu \mathrm{g} / \mathrm{ml})$ at $37^{\circ}$

FIG. 2. Increase in Susceptibility of Cells to Lysozyme by Heat-Treatment, bringing about Nakamura Effect

17) O. Nakamura Z. Immunisatsforsch, 38, 425 (1923). 
with the concentration of lysozyme added to the cell suspension, as presented in Fig. 3. As shown in Fig. 4 , from the activity of clearing and releasing-PNA, the optimum pH of lysozyme action is about 6.0 , while from the activity of increase in viscosity, the optimum $\mathrm{pH}$ seems to be in the vicinity of 7.0. In an incubation with lysozyme at $40^{\circ}$ for $2 \mathrm{hr}$, , the supernatant of the cell-suspension was found to give rise to turbidity

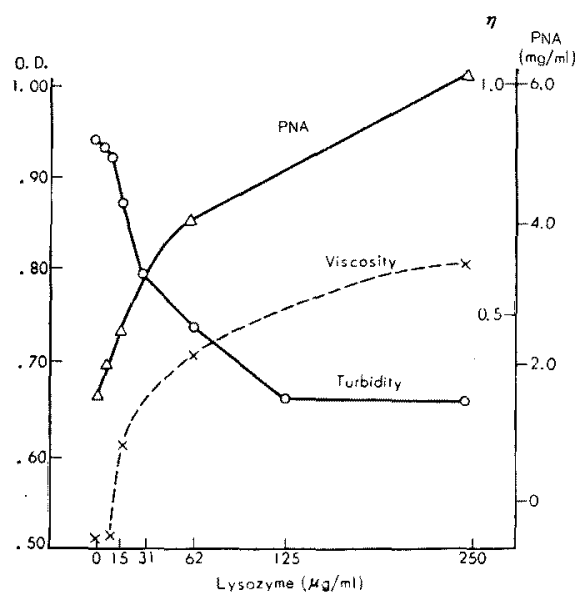

(incubation with cells for $2 \mathrm{hr}$ )

FIG. 3. Relation of Lysozyme-Concentration with Nakamura Effect on Cells heated at $60^{\circ}$ for $10 \mathrm{~min}$.

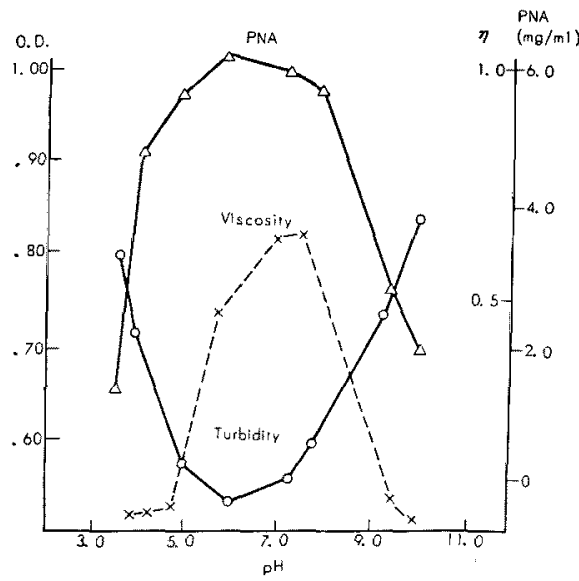

FIG. 4. Effect of $\mathrm{pH}$ on Sensitivity of Heated Cells $\left(60^{\circ}, 10 \mathrm{~min}\right.$.) to Lysozyme, bringing Nakamura Effect $2 \mathrm{hr})$

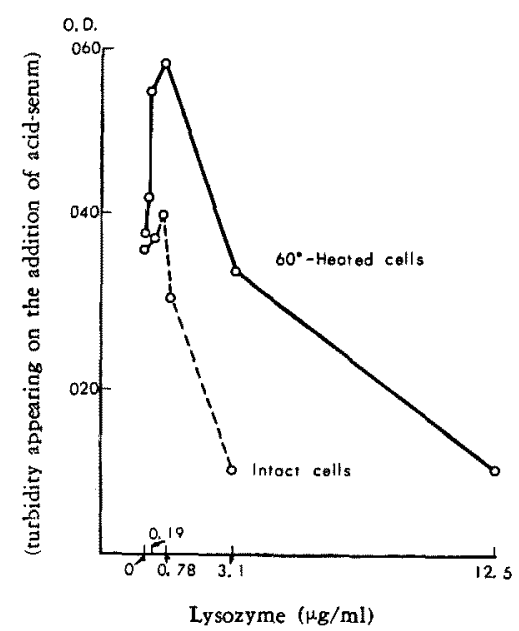

FIG. 5. Release and Dissolution of Cell-Wall Mucopolysaccharide during Incubation with Lysozyme

upon the addition of an acidified horse serum. Hence, a certain kind of mucopolysaccharide was considered to be dissolved-out from the cell-walls during incubation. In Fig. 5 the turbidity appearing in such treatment with various concentrations of lysozyme is shown. It is noticeable, that in the curve there seems to exist optimal concentration to give maximal turbidity and an excess of lysozyme decrease, in proportion to remarkably the concentration, the turbidity. This phenomenon is most probably due to hydrolysis of mucopolysaccharide by an excess of lysozyme into the nonprecipitable fraction with acid serum. With intact cells, the dissociation of mucopolysaccharide was found to be far weaker than that of heated cells. Also, the mucopolysaccharide revealed to contain a large amount of glucosamine as its main sugar component, by a paperchromatography following acid hydrolysis.

\section{DISCUSSION}

The significance of effects of heat-treatment on susceptibility of acid-fast cells to lysozyme was recognized in the heat-treatment at about $60^{\circ}$. W. B. Redmond and his coworker ${ }^{18)}$ have reported on the autolysis of a tubercle bacillus grown in a nitrogen-deficient medium where autolytic enzymes were either unaffected or

18) W.B. Redmond and B. U. Bowman, J. Bacteriol., 69, 293 (1955). 
little affected by heating at $56^{\circ}$ for $30 \mathrm{~min}$. In some gram-negative bacteria, it has been demonstrated that disorganization of the cellwall brought about by physico-chemical ${ }^{52,6,77}$ or a certain antibiotic treatment, results in the acceptance of lysozyme action ${ }^{19)}$. Howere, the polysaccharide substrate of lysozyme in the acid-fast cells present in the complex with other cellular constituents may not be considered to accept the action of lysozyme directly, after undergoing any change in the permeabilitybarriers by heat-treatment, as has been mentioned previously by M.E. Becker and S. E. Hartsell $^{6}$. It seems reasonable to assume that some autolytic enzymes which can split the complex structure of cell-surface substances would be activated by the heat-treatment, whereby a structural-site for the acceptance of lysozyme appears.

The difference between the action of eggwhite and bacterial lysozyme on acid-fast cells indicates that the former enzyme ${ }^{20)}$ has a comparatively broad specificity as a polyglucosaminidase for the bacterial substrates while the latter a somewhat limited specificity. From this fact, the use of the bacterial lysozyme may offer a new tool for a more fundamentary study of the chemical constitution of bacterial cellwall susceptible to lysozyme.

From the experiments described above, the main factors causing the synergistic effect within lysozyme and other enzymes are not considered to involve any of the following enzymes: protease, nuclease, lipase, phospholipase and ester: ases. But the factors are thought to be some sort of polysaccharidase commonly found in fungi just like those of Sclerotinia fungus,

19) G. H. Warren, J. Gray and J. A. Yurchenco, J. Bacteriol, 74788 (1957).

20) L. R. Berger and R. S. Weiser, Biochim. Brophys. Acta, 26, 517 (1957). such as chitinase, cellulase, lichenase, polyglu$\operatorname{cosanase}^{21}$ and protopectinase etc. Recently, A. Sohler and his coworkers ${ }^{22)}$ reported that the different sensitivities of Actinomycetales to lysozyme, could be explained by the difference in carbohydrate composition of the cell-wall, and the lysozyme-resistant strain contained only a small amount of hexosamine contrary to its richness in arabinose and galactose. Lysozyme and other lytic factors should operate alternatively to dissolute the complex structure of the cell-wall, stepwisely removing the obstructive sites.

\section{SUMMARY}

(1) Non acid-fast cells of an avian tubercle bacillus were easily lysed by lysozyme, whereas acid-fast cells could be digested by a successive attack of lysozyme followed by Sclerotiniaenzyme. Bacterical lysozyme, trypsin and pancreatin, however, had no synergistic action with lysozyme. The synergistic factor contained in the Sclerotinia-enzyme extract was assumed to be a certain polysaccharidase.

2) The release of a mucopolysaccharide from the cell-wall during incubation with lysozyme increased by previously heating the cells at about $60^{\circ}$ for $10 \mathrm{~min}$. The effect of heat-treatment upon the sensitivity of cells to lysozyme, which was accompanied by a remarkable $\mathrm{Na}$ kamura effect, was concluded to be due to the activation of some autolytic enzymes.

The authors wish to express their thanks to Dr. I. Yamasaki, for reading this manuscript. They are also indebted to Mr. Y. Nishikawa and $\mathrm{Mr}$. M. Ono, for their assistance in part of these experiments.

21) R. A. Aitken, B. P. Eddy, M. Ingram and C. Weurman, Biocbem. J., 64, 63 (1957).

22) A. Sohter, A. H. Romano and W. J. Nickerson, J. Bacteriol., $75,283(1958)$ 